\title{
ANALISIS MOTOR INDUKSI FASA TIGA TIPE ROTOR SANGKAR SEBAGAI GENERATOR INDUKSI DENGAN VARIASI HUBUNGAN KAPASITOR UNTUK EKSITASI
}

\author{
Rahmi Berlianti \\ Program Studi Teknik Listrik, Jurusan Teknik Elektro \\ Politeknik Negeri padang \\ e-mail: rh14_85@yahoo.co.id
}

\begin{abstract}
Abstrak-Motor induksi fasa tiga dapat dapat dioperasikan sebagai generator induksi fase tiga. Kecenderungan menggunakan generator induksi (rotor sangkar) sebagai pengganti generator sinkron juga semakin meningkat khususnya untuk PLTMh kecil dengan beban penerangan (resistif). Hal ini dikarenakan alasan perawatannya rumit, susah didapat dipasaran, dan harganya mahal. Generator induksi penguatan sendiri, memiliki banyak keuntungan dibandingkan dengan generator sinkron. Akan tetapi generator induksi menawarkan regulasi tegangan yang lemah dan nilainya bergantung pada kecepatan penggerak, kapasitor, dan beban. Pada penelitian ini digunakan motor induksi fasa tiga rotor sangkar $0,9 \mathrm{KW}, 2,7$ A, pf 0,84, $50 \mathrm{~Hz}$ sebagai generator induksi, dengan variasi hubungan kapasitor dimana nilai kapasitansi untuk hubungan Bintang $25 \mu \mathrm{F}$, Delta $8 \mu \mathrm{F}$, dan C-2C $8 \mu \mathrm{F}$ dan $16 \mu \mathrm{F}$ untuk beban R-RL yang variatif. Dan dari ketiga hubungan kapasitor tersebut yang lebih baik adalah hubungan bintang dengan kapasitansi 25 $\mu \mathrm{F}$.
\end{abstract}

Kata kunci : motor induksi, generator induksi, kapasitor, bintang, delta, C-2C, fasa tiga, penguatan sendiri

\begin{abstract}
Three-phase induction motor can be operated as a three-phase induction generator.The tendency to use induction generators (rotor cage) as subtitute of a synchronous generator is also increasing, especially for small MHP with lighting load (resistive). Its because of the dificulty, hard to find in the market, and high cost,induction generator self-excitation has many advantages than synchronous generator. However, the induction generator offers low voltage regulation and its value depends on the driving speed, capacitors, and the load. In this study, a three-phase induction motor ( rotor cage) $0.9 \mathrm{KW}, 2.7 \mathrm{~A}, \mathrm{pf} 0.84,50 \mathrm{~Hz}$ used as an induction generator, with capasitor connection variety, which capasitance value for star $25 \mu \mathrm{F}$, Delta $8 \mu \mathrm{F}, \mathrm{C}-2 \mathrm{C} 8 \mu \mathrm{F}$ and $16 \mu \mathrm{F}$ to load R-RL varied. And star connection capasitor with $25 \mu \mathrm{F}$ capasitance is better than others.
\end{abstract}

Keywords: induction motor, induction generators, capacitors, star, delta, C-2C, phase-three, self exitation

\section{PENDAHULUAN}

Keterbatasan ketersedian bahan bakar ini serta kepedulian terhadap lingkungan meningkatkan perkembangan teknologi pembangkit listrik energi terbarukan. Namun penggunaan sumber energi terbarukan seperti angin dan air sering mengalami kendala berupa kecepatan alirannya yang bervariasi dan tidak konstan.

Sistem generator yang biasanya digunakan (non-variable speed sistem) tidak dapat mengekstrak daya secara optimum serta tegangan yang dihasilkan memiliki amplitudo yang berubah-ubah pula sehingga mengakibatkan kualitas daya yang dihasilkan jelek.
Secara eksternal penggunaan mesin induksi dapat disesuaikan dengan nilai kapasitor bank yang digunakan pada generator. Sistem ini disebut dengan generator induksi penguatan sendiri atau Self-excited induction generator (SEIG). SEIG ini memiliki banyak keuntungan dibandingkan dengan generator sinkron seperti tidak perlu sikat-sikat atau baling-baling rotor, pengurangan ukuran, dan harga yang murah. Akan tetapi generator induksi menawarkan regulasi tegangan yang lemah dan nilainya bergantung pada kecepatan penggerak, kapasitor dan beban [1].

Kecenderungan menggunakan generator induksi (rotor sangkar) sebagai pengganti generator sinkron juga semakin meningkat khususnya untuk PLTMh kecil dengan beban penerangan (resistif). Generator Induksi adalah 
motor induksi yang dioperasikan sebagai generator dengan penambahan kapasitor penguat atau kapasitor eksitasi pada terminal motor. Kapasitor yang digunakan pada generator umumnya adalah kapasitor tetap. Pada PLTMh berkapasitas1-3 KW sangat tidak efisien jika menggunakan generator sinkron sebagai pembangkitnya dengan alasan perawatannya rumit, susah didapat dipasaran, dan harganya mahal. Oleh sebab itu perlu dicari alternatif pengganti generator sinkron untuk mikrohidro skala 1-3 KW.

\section{LANDASAN TEORI}

\subsection{Prinsip kerja Motor induksi}

Motor induksi bekerja berdasarkan induksi elektromagnetik dari kumparan stator kepada kumparan rotornya. Apabila sumber tegangan tiga fasa dipasang pada kumparan stator, timbulah medan putar dengan kecepatan

$N_{S}=\frac{120 f}{P}$

Medan putar stator tersebut akan memotong batang konduktor pada rotor, sehingga pada kumparan rotor akan timbul tegangan induksi atau gaya gerak listrik (ggl ) perfasa sebesar :

$$
E_{r}=4,44 f_{s} N_{r} \Phi_{m}
$$

Karena kumparan rotor merupakan rangkaian yang tetutup, ggl (E) akan menghasilkan arus (I). Adanya arus (I) di dalam medan magnet menimbulkan gaya $(\mathrm{F})$ pada rotor. Bila kopel mula yang dihasilkan oleh gaya Lorenz $(\mathrm{F})$ pada rotor cukup besar untuk memikul kopel beban, rotor akan berputar searah dengan medan putar stator. Seperti yang sudah disebutkan sebelumnya bahwa tegangan induksi timbul karena terpotongnya batang konduktor rotor oleh medan magnet putar stator. Artinya agar adanya tegangan terinduksi maka diperlukan relatif antara kecepatan medan magnet putar stator $\left(\mathrm{N}_{\mathrm{s}}\right)$ dan kecepatan putar rotor $\left(\mathrm{N}_{\mathrm{r}}\right)$. Dan perbedaan antara $\mathrm{N}_{\mathrm{s}}$ dan $\mathrm{N}_{\mathrm{r}}$ ini disebut dengan slip (S). yang dinyatakan dengan :

$$
S=\frac{\left(N_{S}-N_{r}\right)}{N_{s}} x 100 \%
$$

Bila $\mathrm{N}_{\mathrm{r}}=\mathrm{N}_{\mathrm{s}}$, tegangan tidak akan terinduksi dan arus tidak mengalir pada kumparan jangkar rotor, dengan demikiantidak dihasilkan kopel. Kopel motor akan timbul bila $\mathrm{N}_{\mathrm{r}}<\mathrm{N}_{\mathrm{s} .}$ Dilihat dari cara kerjanya, motor induksi disebut juga sebagai motor tak serempak atau asinkron.

\subsection{Slip}

Apabila rotor dari motor induksi berputar dengan kecepatan $\mathrm{N}_{\mathrm{r}}$, dan medan magnet stator berputar dengan kecepatan $\mathrm{N}_{\mathrm{s}}$, maka bila ditinjau perbedaan kecepatan relatif antara kecepatan medan magnet putar stator terhadap kecepatan rotor, ini disebut kecepatan slip yang besarnya sebagai berikut [2] :

$$
\text { Kecepatan Slip }=N_{s}-N_{r}
$$

Persamaan 3 dapat juga ditulis :

$$
N_{r}=\frac{120 . f}{P}(1-S)
$$

Dengan demikian persamaan 3 menjadi :

$$
\left(N_{S}-N_{r}\right)=S \cdot N_{S}
$$

\subsection{Prinsip Kerja Dan Proses Pembangkitan Generator Induksi. \\ Prinsip kerja generator induksi adalah} kebalikan daripada kerja motor induksi. Dimana motor berfungsi sebagai motor, kumparan stator diberi tegangan tiga fasa maka akan timbul medan putar dengan kecepatan sinkron. Dan jika motor digunakan sebagai generator maka rotor diputar dengan kecepatan yang lebih besar dari kecepatan sinkronnya. Dengan kecepatan rotor yang melebihi kecepatan sinkron dapat dikatakan generator induksi bekerja pada slip negatif.

Pada saat motor induksi digunakan sebagai generator induksi maka diperlukan daya reaktif atau daya magnetisasi untuk menghasilkan tegangan pada terminal keluarannya. Dan yang berfungsi sebagai penyedia daya reaktif adalah kapasitor yang besarnya disesuaikan dengan kebutuhan daya reaktif.

Kebutuhan daya reaktif dapat dipenuhi dengan memasang satu unit kapasitor pada terminal keluaran, dimana kapasitor menarik daya reaktif kapasitif atau dengan kata lain kapasitor memberikan daya reaktif induktif 
pada mesin induksi, dan proses ini disebut dengan sistem penguat(eksitasi). Sehingga generator induksi disebut juga generator induksi penguatan sendiri.

Hal yang perlu diperhatikan dalam kinerja generator induksi adalah fluksi sisa atau medan magnet pada stator,karena jika fluksi sisa ini tidak ada maka proses pembangkitan tegangan tidak akan terjadi. Dengan adanya fluksi pada rotor maka tegangan induksi akan terinduksi juga pada bagian stator sehingga menimbulkan arus yang akan mengisi kapasitor hingga terjadi keseimbangan. Keseimbangan tersebut ditandai dengan titik pertemuan antara lengkung magnetisasi dengan reaktansi kapasitif seperti pada gambar 1 Lengkung magnetisasi ini terjadi akibat adanya kejenuhan dari inti besi mesin [4].

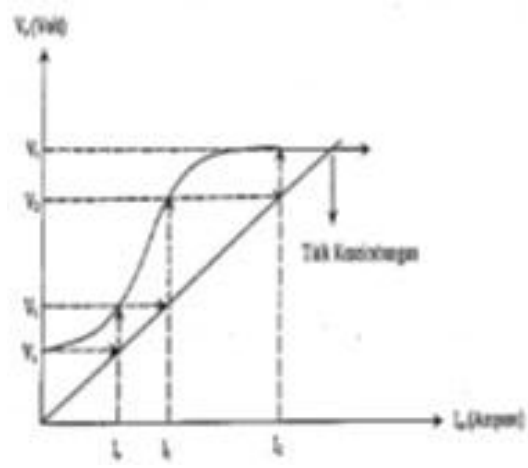

Gambar 1. Proses Penguatan

\subsection{Kebutuhan Daya Reaktif Generator Induksi}

Kebutuhan daya reaktif dari suatu motor induksi yang difungsikan sebagai generator induksi dapat dicatu oleh beberapa kapasitor yang dipasang secara parallel pada kumparan stator. Tegangan pada terminal akan timbul setelah dipasang kapasitor yang mana besar nilai kapasitor tersebut harus lebih besar dibandingkan saat dioperasikan sebagai motor induksi.

Nilai minimum dari kapasitor untuk membangkitkan daya reaktif pada generator induksi dirumuskan sebagai berikut [3]

$$
\begin{array}{r}
S=V_{k} I_{k} \\
P=V_{k} . I_{k} \cos \varphi=S \cos \varphi \\
Q=V_{k} . I_{k} \sin \varphi=S \sin \varphi
\end{array}
$$

Dimana :

$$
\begin{array}{llr}
\mathrm{S} & =\text { daya semu } & \text { (VA) } \\
\mathrm{P} & =\text { daya aktif (nyata) } & \text { (watt) } \\
\mathrm{Q} & =\text { daya reaktif } & \text { (VAR) } \\
\mathrm{Vk} & =\text { tegangan kawat } & \text { (V) } \\
\mathrm{Ik} & =\text { arus kawat } & \text { (A) } \\
\Phi & =\text { sudut fasa } & \left({ }^{0}\right)
\end{array}
$$

\subsection{Kapasitor Terhubung Bintang Dan Delta}

Untuk memperkirakan nilai kapasitor penguat yang dibutuhkan generator induksi dengan model generator hubungan bintang dan kapasitor hubungan bintang atau delta digunakanlah grafik seperti pada gambar 2 dibawah ini :

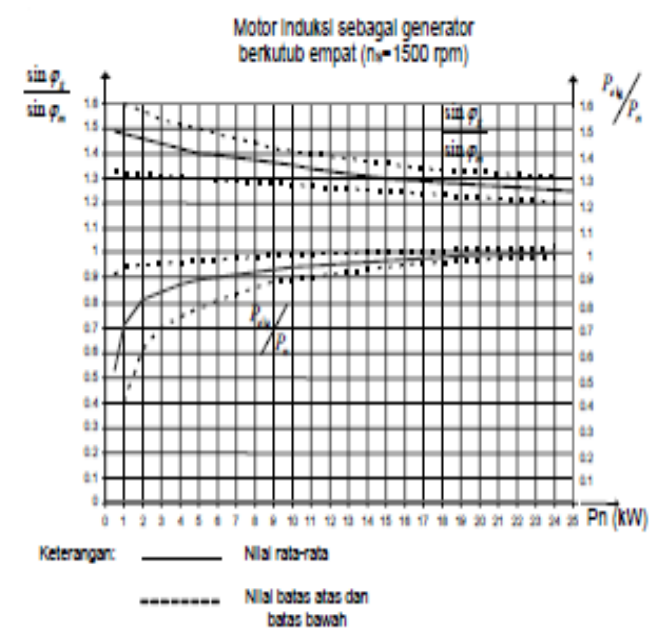

Gambar 2. Rasio Sin $\Phi$ Generator Dan Sin $\Phi$

Motor Serta Daya Motor Dan Generator Sebagai Rating Fungsi Daya Nominal Motor

$$
P_{n}[6] .
$$

Suatu motor induksi tiga fasa dengan daya nominal $\mathrm{P}_{\mathrm{n}}$, efisiensi motor $\eta_{\mathrm{m}}$, tegangan kerja $\mathrm{U}$, dan factor daya pf difungsikan sebagai generator induksi, maka nilai kapasitor yang dipasang sebagai penguat pada terminal ditentukan dengan persamaan [6].

$C_{\Delta \text { per fasa }}=\frac{\Delta Q}{3 U^{2} 2 \pi f}$

Dimana :

$\mathrm{U}$ : tegangan fasa ke fasa (jika terhubung delta) $\mathrm{F}$ : frekuensi jaringan $\Delta \mathrm{Q}$ : daya reaktif yang dikompensasi 
Daya keluaran mesin saat digunakan sebagai generator adalah :

$$
P_{e l g}=k_{1} P_{n}
$$

Dimana nilai $\mathrm{k}_{1}$ ditentukan dari grafik pada gambar 2 Daya listrik masukan pada saat mesin menjadi motor $\left(\mathrm{P}_{1}\right)$ dan daya reaktif motor saat beban nominal $\left(\mathrm{Q}_{\mathrm{m}}\right)$ adalah :

$$
\begin{aligned}
& P_{1}=\frac{P_{n}}{\eta_{m}} \\
& Q_{m}=P_{1} \tan (\varnothing) \\
& \varnothing=\cos ^{-1}(p f)
\end{aligned}
$$

Dengan menggunkan grafik pada gambar 2 dapat dikethui rasio antar kebutuhan daya reaktif motor dan generator yang diwakili oleh perbandingan $\sin \Phi$, yaitu :

$$
\frac{\sin \emptyset_{g}}{\sin \emptyset_{m}}=k_{2}
$$

Daya reaktif generator selanjutnya ditentukan dengan persamaan berikut :

$\Delta Q=Q_{g}=k_{2} Q_{m}$

Dan nilai kapasitor penguat dengan metode ini diperoleh dari persamaan 2.17. Jika kapasitor penguat terhubung bintang maka nilai kapasitor penguatnya adalah:

$$
C_{Y}=3 C_{\Delta}
$$

\subsection{Kapasitor Terhubung C-2C}

Pada hubungan kapasitor C-2C maka motor induksi rotor sangkar tiga fasa hubungan delta dioperasikan seakan akan sebagai generator fasa tunggal. Untuk suatu motor induksi tiga fasa dengan tegangan antar fasa $\mathrm{V}_{\mathrm{L}}$ $\mathrm{L}$ terhubung delta, faktor daya $\mathrm{pf}$ dan arus beban penuh $\mathrm{I}_{\mathrm{FL}}$ maka daya semu total (S) dinyatakan dengan :

$$
S=\sqrt{3} V_{L-L} I_{F L} .
$$

Daya nyata total adalah :

$$
P=S \cos \phi=S . p f
$$

menggunakan hubungan segitiga daya maka dapat diketahui daya reaktif total (Q), yaitu :

$Q=\sqrt{S^{2}-P^{2}}$

dan daya reaktif perfasa

$$
Q_{\text {fasa }}=Q / 3
$$

Jika kapasitor terhubung C-2C berlaku

$V_{L-L}=V_{\text {fasa }}$

dan arus fasa

$I_{\text {fasa }}=Q_{\text {fasa }} / V_{\text {fasa }}$

Oleh sebab itu nilai kapasitor penguat perfasa dengan menggunakan metode C-2C ditentukan dengan persamaan

$$
\begin{aligned}
& C_{1}=\frac{I_{\text {fasa }}}{2 \pi f V_{\text {fasa }}} \\
& C_{2}=2 C_{1}
\end{aligned}
$$

\section{RANGKAIAN PENGUJIAN}

\subsection{Rangkaian Pengujian Generator Induksi Hubungan Bintang (Y) Dengan Kapasitor Hubungan Bintang (Y)}

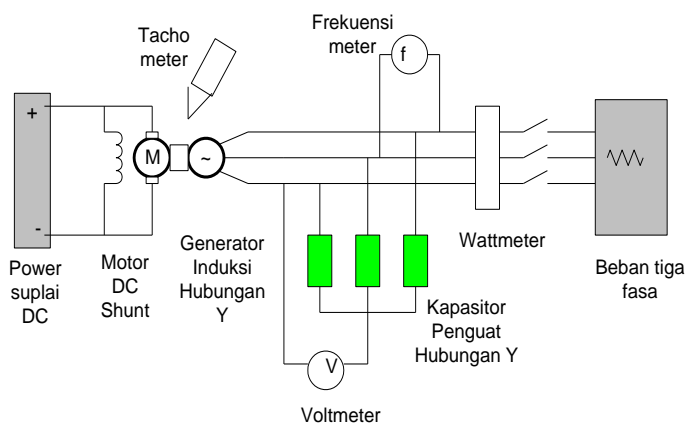

Gambar 3. Rangkaian Generator Hubungan Bintang Dengan Kapasitor Hubungan Bintang 
3.2. Generator Induksi Hubungan Bintang (Y) Dengan Kapasitor Hubungan Delta ( $\Delta)$

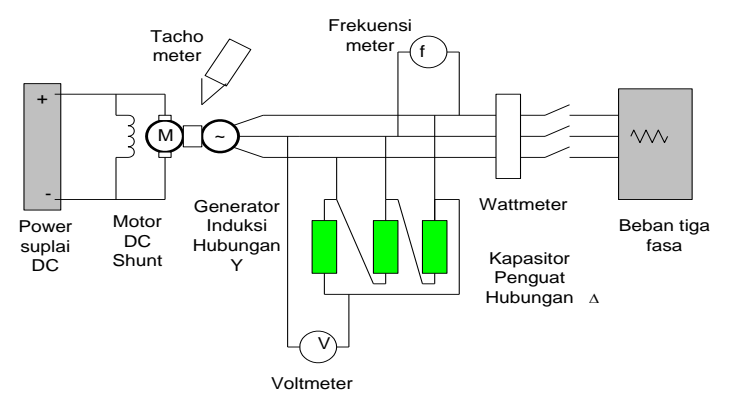

Gambar 4. Rangkaian Generator Hubungan Bintang Dengan Kapasitor Hubungan Delta

3.3. Generator Induksi Hubungan Delta $(\Delta)$ Dengan Kapasitor Hubungan C-2C

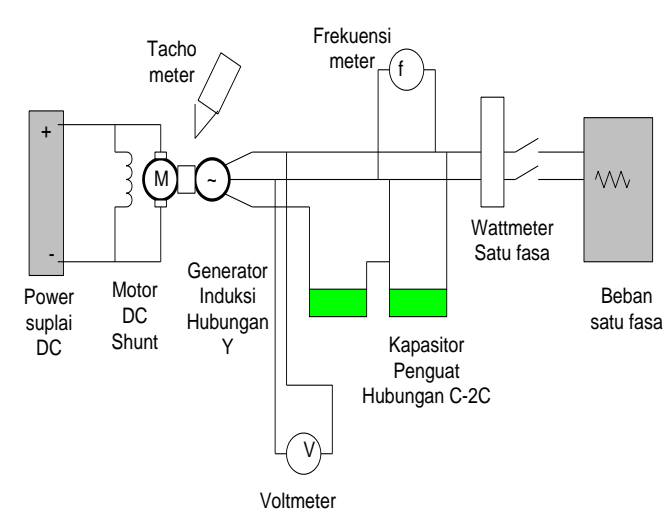

Gambar 5. Rangkaian Generator Hubungan Bintang Dengan Kapasitor Hubungan C-2C

\subsection{Kebutuhan Kapasitansi Kapasitor Sesuai dengan Plat Nama}

\section{Kapasitor Terhubung Delta}

Dengan menggunakan persamaan 2.19 dan 2.20 maka dihitung daya $P_{l}$ dan daya reaktif motor $Q_{m}$ dengan efisiensi motor diasumsikan 0,9 adalah :

$$
\begin{aligned}
P_{1} & =\frac{P_{n}}{\eta_{m}}=\frac{0,9}{0,9} \\
& =1 K W \\
\emptyset & =\cos ^{-1} \varphi \\
& =32,86 \\
Q_{m} & =P_{1} \tan \emptyset
\end{aligned}
$$

$$
\begin{aligned}
& =1 \tan 32,86 \\
& =645,93 \mathrm{VAR}
\end{aligned}
$$

Dengan merujuk pada grafik gambar 2, maka nilai k2 diperoleh sebesar 1,49 jadi berdasarkan rumus 2.23 daya reaktif generator adalah sebesar:

$$
\begin{aligned}
\Delta Q & =k_{2} . Q_{m} \\
& =1,49.645,9 \\
& =962,4 \text { VAR }
\end{aligned}
$$

Jadi besarnya nilai kapasitansi kapasitor untuk hubungan delta diperoleh dengan menggunakan rumus 2.17 berikut :

$$
\begin{aligned}
C_{\Delta} & =\frac{\Delta Q}{3 U^{2} 2 \pi f} \\
= & =\frac{962,435}{3.380^{2} \cdot 2 \cdot 3,14.50} \\
& =7,07 \mu \mathrm{F}
\end{aligned}
$$

\section{Kapasitor Terhubung Bintang}

Untuk menentukan besarnya nilai kapasitansi kapasitor untuk hubungan bintang maka digunakan rumus 2.24 Seperti berikut ini:

$$
\begin{aligned}
C_{Y} & =3 C_{\Delta} \\
& =3 \times 7,07 \\
& =21,226 \mu \mathrm{F}
\end{aligned}
$$

\section{Kapasitor Terhubung C-2C}

Dengan menggunakan rumus 2.28 dan 2.29, maka akan didapatkan nilai dari $Q_{\text {fasa }}$ dan $I_{\text {fasa }}$ berikut :

$$
\begin{aligned}
S & =\sqrt{3} \cdot V_{L} \cdot I_{L} \\
& =\sqrt{3.380} \cdot 2,7 \\
& =1777,084 \mathrm{VA} \\
P & =S \cos \emptyset \\
& =1777,084.0,84 \\
& =1492,75 \mathrm{Watt} \\
Q & =\sqrt{S^{2}-P^{2}} \\
& =\sqrt{(1777,084)^{2}-(1492,75)^{2}} \\
& =1964,22 \mathrm{VAR}
\end{aligned}
$$




$$
\begin{aligned}
Q_{\text {fasa }} & =\frac{Q}{3} \\
& =\frac{1964,22}{3}=321,407 \mathrm{VAR} \\
I_{\text {fasa }} & =\frac{Q_{\text {fasa }}}{V_{\text {fasa }}} \\
& =\frac{321,407}{380}=0,8458 \mathrm{~A}
\end{aligned}
$$

Dan untuk menentukan besarnya nilai kapasitansi kapasitor untuk hubungan C-2C maka digunakanlah rumus 2.30 dan 2.31 seperti dibawah ini :

$$
\begin{aligned}
C_{1} & =\frac{I_{\text {fasa }}}{2 \pi f V_{\text {fasa }}} \\
& =\frac{0,8458}{2.3,14.50 .380} \\
& =7,0885 \mu \mathrm{F} \\
C_{2} & =2 C_{1} \\
& =2.7,0885 \\
& =14,117 \mu \mathrm{F}
\end{aligned}
$$

\section{HASIL PENGUJIAN}

\subsection{Pengujian Tanpa Beban}

Pada pengujian ini dilakukan pengukuran pada rangkaian seperti pada gambar 3, 4 dan 5 tanpa diberi beban apapun, sehingga diperoleh data pada tabel 4.1 dibawah ini :

Tabel 4.1 Data Pengujian Tanpa Beban

\begin{tabular}{|c|c|c|c|}
\hline Tegangan & Frekuensi & Putaran & \multirow{2}{*}{$\begin{array}{c}\text { Hub. } \\
\text { Kapasitor }\end{array}$} \\
\cline { 1 - 3 }$(\mathbf{V L N})$ & $(\mathbf{H z})$ & $\mathbf{( R p m )}$ & Y \\
\hline 220 & 51 & 1546 & $\Delta$ \\
\hline 220 & 44 & 1280 & $\Delta$ \\
\hline 220 & 45 & 1320 & C - 2C \\
\hline
\end{tabular}

Berdasarkan hasil pengukuran tanpa beban seperti yang terlihat pada tabel 4.1 maka dapat kita lihat bahwa dari ketiga model rangkaian penelitian yang menunjukan hasil yang lebih baik adalah hubungan kapasitor bintang dengan tegangan $220 \mathrm{~V}$,frekuensi $51 \mathrm{~Hz}$ dan putaran $1546 \mathrm{rpm}$. Disini terlihat jelas bahwa hubungan kapasitor mempengaruhi nilai frekuensi dan putaran generator pada saat tegangan konstan.

\subsection{Pengujian Untuk Kapasitor Hubungan Bintang Beban Resistif (R)}

Untuk pengujian ini pada belitan stator generator induksi yang terhubung bintang dihubungkan dengan kapasitor yang terhubung bintang juga dan kemudian dibebani dengan beban resistif yang bervariasi sampai dengan keadaan beban maksimum. Tabel 4.2 berikut memperlihatkan hasil dari pengujian kapasitor terhubung bintang dengan nilai $25 \mu \mathrm{F}$.

\section{- Untuk tegangan konstan $220 \mathrm{~V}$}

Tabel 4.2 Hasil Pengujian Hubungan Kapasitor Bintang Dengan Beban Resistif Dan Tegangan Konstan

\begin{tabular}{|c|c|c|c|}
\hline Tegangan & Frekuensi & Beban & Putaran \\
\hline (VLN) & $(\mathbf{H z})$ & (Watt) & $($ Rpm) \\
\hline 220 & 51 & 15 & 1571 \\
\hline 220 & 52 & 25 & 1582 \\
\hline 220 & 52 & 40 & 1623 \\
\hline 220 & 53 & 100 & 1650 \\
\hline 220 & 53 & 115 & 1681 \\
\hline
\end{tabular}

Pada hubungan kapasitor bintang ini nilai kapasitor yang digunakan $25 \mu \mathrm{F}$ adalah nilai kapasitor yang mendekati nilai $21,226 \mu \mathrm{F}$ dari hasil perhitungan yang ada dipasaran saat penelitian dilakukan.

\section{- Untuk frekuensi konstan $50 \mathrm{~Hz}$}

Tabel 4.3 Hasil Pengujian Hubungan Kapasitor Bintang Dengan Beban Resistif Dan Frekuensi Konstan

\begin{tabular}{|c|c|c|c|}
\hline Tegangan & Frekuensi & Beban & Putaran \\
\hline$($ VLL) & $(\mathbf{H z})$ & $\mathbf{( W )}$ & $\mathbf{( R p m )}$ \\
\hline 371 & 50 & 15 & 1503 \\
\hline 370 & 50 & 25 & 1503 \\
\hline 363 & 50 & 40 & 1503 \\
\hline 324 & 50 & 100 & 1503 \\
\hline 165 & 50 & 115 & 1503 \\
\hline
\end{tabular}

\subsection{Pengujian Untuk Kapasitor HubunganBintang Beban Resistif Induktif (RL)}

Untuk pengujian dengan beban RL ini maka generator induksi dengan kapasitansi kapasitor sebesar $25 \mu \mathrm{F}$ diberi beban resistif induktif yang bervasiasi. Disini beban induktif yang diberikan sebesar 4,8 $\mathrm{H}$ yang diparalel dengan beban resistif yang bervariasi. Berikut adalah hasil dari pengujian.

- Untuk tegangan konstan $220 \mathrm{~V}$ 
Tabel 4.4 Hasil Pengujian Hubungan Kapasitor Bintang Dengan Beban Resistif Induktif Dan Tegangan Konstan

\begin{tabular}{|c|c|c|c|c|}
\hline $\begin{array}{c}\text { Teganga } \\
\mathbf{n}\end{array}$ & $\begin{array}{c}\text { Frekuens } \\
\mathbf{i}\end{array}$ & Beban R & Beban L & $\begin{array}{c}\text { Putara } \\
\mathbf{n}\end{array}$ \\
\hline (VLN) & $(\mathbf{H z})$ & $($ Watt) & $(\mathbf{H})$ & $\begin{array}{c}\text { Rpm } \\
\text { ) }\end{array}$ \\
\hline 220 & 52 & 15 & 4,8 & 1615 \\
\hline 220 & 53 & 25 & 4,8 & 1626 \\
\hline 220 & 53 & 40 & 4,8 & 1645 \\
\hline 220 & 54 & 100 & 4,8 & 1671 \\
\hline 220 & 55 & 115 & 4,8 & 1690 \\
\hline
\end{tabular}

- Untuk frekuensi konstan $50 \mathrm{~Hz}$

Tabel 4.5 Hasil Pengujian Hubungan Kapasitor Bintang Dengan Beban Resistif Induktif Dan Frekuensi Konstan

\begin{tabular}{|c|c|c|c|c|}
\hline Tegangan & Frekuensi & $\begin{array}{c}\text { Beban } \\
\text { R }\end{array}$ & Beban L & Putaran \\
\hline VLL $(\mathbf{V})$ & $(\mathbf{H z})$ & $(\mathbf{W})$ & $\mathbf{H}$ & $(\mathbf{r p m})$ \\
\hline 374 & 50 & 15 & 4,8 & 1503 \\
\hline 367 & 50 & 25 & 4,8 & 1503 \\
\hline 353 & 50 & 40 & 4,8 & 1503 \\
\hline 350 & 50 & 100 & 4,8 & 1503 \\
\hline 349 & 50 & 115 & 4,8 & 1503 \\
\hline
\end{tabular}

\subsection{Pengujian Untuk Kapasitor Hubungan Delta Beban Resistif (R)}

Pada pengujian ini generator terhubung bintang dan kapasitor terhubung delta pada kumparan stator generator dengan nilai kapasitansi kapasitor sebesar $8 \mu \mathrm{F}$, nilai ini merupakan nilai yang dibulatkan dari hasil perhitungan sebesar $7,07 \mu \mathrm{F}$ disini generator dibebani dengan beban resisistif yang bervariasi sehingga diperoleh hasil pengujian pada tabel dibawah ini :

- Untuk tegangan konstan $220 \mathrm{~V}$

Tabel 4.6 Hasil Pengujian Hubungan Kapasitor Delta Dengan Beban Resistif Pada Tegangan Konstan

\begin{tabular}{|c|c|c|c|}
\hline Tegangan & Frekuensi & Beban & Putaran \\
\hline (VLN) & $(\mathbf{H z})$ & (Watt) & (Rpm) \\
\hline 220 & 45 & 15 & 1285 \\
\hline 220 & 45 & 25 & 1307 \\
\hline 220 & 46 & 40 & 1317 \\
\hline 220 & 46 & 100 & 1358 \\
\hline 220 & 47 & 115 & 1403 \\
\hline
\end{tabular}

- Untuk frekuensi konstan $50 \mathrm{~Hz}$
Tabel 4.7 Hasil Pengujian Hubungan Kapasitor Delta Dengan Beban Resistif Pada Frekuensi Konstan

\begin{tabular}{|c|c|c|c|}
\hline Tegangan & Frekuensi & Beban & Putaran \\
\hline (VLL) & $(\mathbf{H z})$ & $(\mathbf{W})$ & $(\mathbf{R p m})$ \\
\hline 373 & 50 & 15 & 1512 \\
\hline 371 & 50 & 25 & 1512 \\
\hline 363 & 50 & 40 & 1512 \\
\hline 324 & 50 & 100 & 1512 \\
\hline 278 & 50 & 115 & 1512 \\
\hline
\end{tabular}

\subsection{Pengujian Untuk Kapasitor Hubungan}

Delta Beban Resistif Induktif (RL)

Untuk pengujian beban resistif kapasitif ini generator induksi dibebani dengan beban resistif yang berbeda dan diparalelekan dengan beban indukstif sebesar 4,8 $\mathrm{H}$ sehingga diperoleh data penelitian berikut ini :

- Untuk tegangan konstan $220 \mathrm{~V}$

Tabel 4.8 Hasil Pengujian Hubungan Kapasitor Delta Dengan Beban Resistif Induktif Pada Tegangan Konstan

\begin{tabular}{|c|c|c|c|c|}
\hline Tegangan & Frekuensi & Beban & Beban L & Putaran \\
\hline (VLN) & $(\mathbf{H z})$ & (Watt) & $(\mathbf{H})$ & $(\mathbf{R p m})$ \\
\hline 220 & 45 & 15 & 4,8 & 1221 \\
\hline 220 & 45 & 25 & 4,8 & 1287 \\
\hline 220 & 46 & 40 & 4,8 & 1352 \\
\hline 220 & 47 & 100 & 4,8 & 1377 \\
\hline 220 & 47 & 115 & 4,8 & 1413 \\
\hline
\end{tabular}

- Untuk frekuensi konstan $50 \mathrm{~Hz}$

Tabel 4.9 Hasil Pengujian Hubungan Kapasitor Delta Dengan Beban Resistif Induktif Pada Frekuensi Konstan

\begin{tabular}{|c|c|c|c|c|}
\hline Tegangan & Frekuensi & Beban R & Beban L & Putaran \\
\hline VLL & Hz & W & H & Rpm \\
\hline 373 & 50 & 15 & 4,8 & 1512 \\
\hline 366 & 50 & 25 & 4,8 & 1512 \\
\hline 357 & 50 & 40 & 4,8 & 1512 \\
\hline 352 & 50 & 100 & 4,8 & 1512 \\
\hline 350 & 50 & 115 & 4,8 & 1512 \\
\hline
\end{tabular}

\subsection{Pengujian Untuk Kapasitor Hubungan C-2C Beban Resistif (R)}

Pada pengujian ini kumparan stator dari generator terhubung delta yang dihubungkan dengan kapasitor hubungan C-2C. dan generator ini dibebani dengan beban resistif yang bervariasi dan kapasitansi kapasitor 
sebesar 7,089 $\mu \mathrm{F}$ yang kemudian dibulatkan menjadi $8 \mu \mathrm{F}$ dan $14,177 \mu \mathrm{F}$ yang dibulatkan menjadi 16 dan dari hasil pengujiannya maka diperoleh data berikut ini :

\section{- Untuk tegangan konstan $220 \mathrm{~V}$}

Tabel 4.10 Hasil Pengujian Hubungan Kapasitor C-2C Dengan Beban Resistif Pada Tegangan Konstan

\begin{tabular}{|c|c|c|c|}
\hline Tegangan & Frekuensi & Beban & Putaran \\
\hline (VLN) & $(\mathbf{H z})$ & $($ Watt) & $($ Rpm) \\
\hline 220 & 45 & 15 & 1325 \\
\hline 220 & 45 & 25 & 1356 \\
\hline 220 & 46 & 40 & 1371 \\
\hline 220 & 46 & 100 & 1385 \\
\hline 220 & 47 & 115 & 1390 \\
\hline
\end{tabular}

- Untuk frekuensi konstan $50 \mathrm{~Hz}$

Tabel 4.11 Hasil Pengujian Hubungan Kapasitor C-2C Dengan Beban Resistif Pada Frekuensi Konstan

\begin{tabular}{|c|c|c|c|}
\hline Tegangan & Frekuensi & Beban & Putaran \\
\hline (VLN) & $(\mathbf{H z})$ & $(\mathbf{W})$ & $(\mathbf{R p m})$ \\
\hline 377 & 50 & 15 & 1507 \\
\hline 364 & 50 & 25 & 1507 \\
\hline 355 & 50 & 40 & 1507 \\
\hline 347 & 50 & 100 & 1507 \\
\hline 298 & 50 & 115 & 1507 \\
\hline
\end{tabular}

\subsection{Pengujian Untuk Kapasitor Hubungan} C-2C Beban Resistif Indukstif (RL)

Untuk pengujian ini rangkaiannya sama dengan beban $\mathrm{R}$ diatas akan tetapi yang membedakannya adalah beban yang diberikan pada generator induksi adalah beban RL yang bervariasi sehingga diperoleh hasil pengujian sebagai berikut :

- Untuk tegangan konstan $220 \mathrm{~V}$

Tabel 4.12 Hasil Pengujian Hubungan Kapasitor C-2C Dengan Beban Resistif Indukstif Pada Tegangan Konstan

\begin{tabular}{|c|c|c|c|c|}
\hline Tegangan & Frekuensi & Beban R & Beban L & Putaran \\
\hline (VLN) & $(\mathbf{H z})$ & $($ Watt) & $(\mathbf{H})$ & $(\mathbf{R p m})$ \\
\hline 220 & 45 & 15 & 4,8 & 1295 \\
\hline 220 & 45 & 25 & 4,8 & 1301 \\
\hline 220 & 45 & 40 & 4,8 & 1337 \\
\hline 220 & 46 & 100 & 4,8 & 1355 \\
\hline 220 & 46 & 115 & 4,8 & 1378 \\
\hline
\end{tabular}

- Untuk frekuensi konstan $50 \mathrm{~Hz}$

Tabel 4.13 Hasil Pengujian Hubungan Kapasitor C-2C Dengan Beban Resistif Induktif Pada Frekuensi Konstan

\begin{tabular}{|c|c|c|c|c|}
\hline Tegangan & Frekuensi & Beban & Beban & Putaran \\
\hline VLL (V) & $(\mathbf{H z})$ & $(\mathbf{W})$ & H & $(\mathbf{r p m})$ \\
\hline 375 & 50 & 14 & 4,8 & 1507 \\
\hline 368 & 50 & 25 & 4,8 & 1507 \\
\hline 354 & 50 & 40 & 4,8 & 1507 \\
\hline 351 & 50 & 100 & 4,8 & 1507 \\
\hline 350 & 50 & 115 & 4,8 & 1507 \\
\hline
\end{tabular}

\subsection{Perbandingan frekuensi dan tegangan} pada hubungan kapasitor Bintang, Delta dan C-2C

Untuk melihat perbandingan nilai frekuensi dari generator induksi untuk hubungan kapasitor bintang, delta dan C-2C dapat dilihat pada gambar 6 berikut ini :

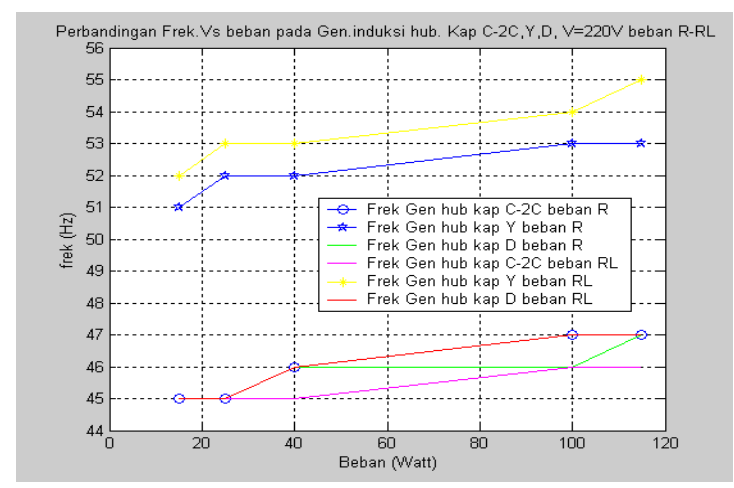

Gambar 6. Grafik Frekuensi Terhadap Beban Untuk Hubungan Kapasitor Bintang, Delta Dan C-2C Dengan Beban R Dan RL Pada Tegangan Konstan

Dari gambar 6 diatas dapat dilihat perbedaan frekuensi pada masing-masing hubungan kapasitor untuk tegangan konstan $220 \mathrm{~V}$ dengan perubahan nilai beban R dan RL. Untuk hubungan bintang memiliki frekuensi yang jauh lebih besar dari hubungan delta dan C-2C yaitu dari 51 sampai $53 \mathrm{~Hz}$. Sedangkan untuk frekuensi hubungan kapasitor delta dan C2C yaitu 45 sampai $47 \mathrm{~Hz}$. Sehingga dilihat dari gambar diatas maka dapat disimpulkan bahwa untuk beban resistif dengan tegangan konstan maka hubungan kapasitor yang baik digunakan pada generator induksi adalah hubungan bintang. 


\subsection{Perbandingan tegangan antara hubungan kapasitor bintang, delta, dan C-2C maka dapat dilihat grafik dibawah ini :}

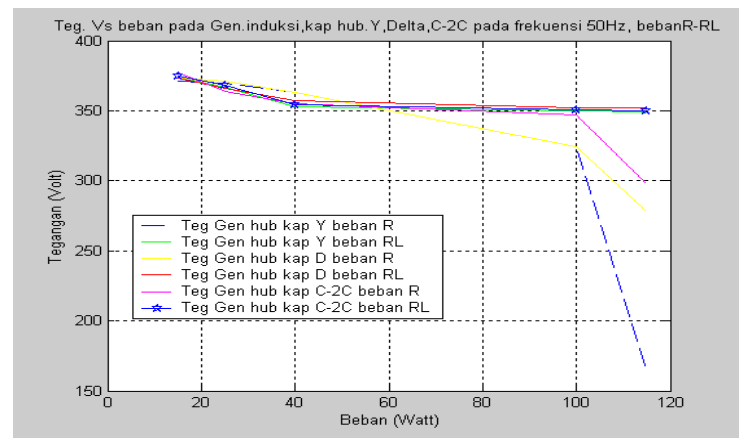

Gambar 7. Grafik Tegangan Terhadap Beban R-RL Pada Hubungan Kapasitor Bintang, Delta Dan C-2C Pada Frekuensi Konstan

Dari gambar 7 dapat dilihat grafik tegangan (VLL) terhadap beban R-RL pada hubungan kapasitor bintang, delta, dan C-2C dengan frekuensi konstan $50 \mathrm{~Hz}$. Disini dapat dilihat untuk beban $\mathrm{R}$ hubungan kapasitor $\mathrm{C}-2 \mathrm{C}$ dibandingkan hubungan bintang dan delta tegangan yang dihasilkan lebih baik, sedangkan untuk beban RL hubungan kapasitor delta lebih baik dari yang lainnya. Sehingga terlihat bahwa hubungan kapasitor mempengaruhi nilai tegangan terhadap beban yang diberikan.

\section{KESIMPULAN}

Dari hasil penelitian yang telah dilakukan pada tesis ini, maka dapat diambil beberapa kesimpulan sebagai berikut :

1. Penggunaan motor induksi sebagai generator hanya digunakan untuk daya-daya yang kecil saja. Karena tegangan keluaran generator sangat dipengaruhi oleh besarnya beban.pada penelitian ini beban maksimumnya adalah $115 \mathrm{~W}$. Jika generator ini diberi beban melebihi kemampuannya maka tegangan generator akan hilang .

2. Dari penelitian yang dilakukan diperoleh data bahwa untuk hubungan kapasitor delta dan C-2C pada tegangan konstan memiliki putaran dibawah putaran sinkron.
3. Pembangkitan tegangan pada generator induksi sangat dipengaruhi oleh nilai kapasitansi dan bentuk hubungan kapasitornya. Untuk beban resistif dan resistif induktif pada generator induksi tiga fasa $0,9 \mathrm{KW}, 2,7 \mathrm{~A}$, pf $0,84,50 \mathrm{~Hz}$ tegangan konstan $220 \mathrm{~V}$ maka hubungan kapasitor yang lebih baik digunakan adalah hubungan bintang dengan nilai $25 \mu \mathrm{F}$ karena pada kondisi ini frekuensi dan putaran motornya lebih stabil.

\section{DAFTAR PUSTAKA}

[1]. Jose Antonio Barrado., Robert Grino., Analysis Of Voltage Control For A Selfexcited Induction Generator Using A Three-Phase Four-Wire Electronic Converter. Espana.(2007)

[2]. Drs. Yon Rijono., Dasar Teknik Tenaga Listrik, Edisi Revisi,Penerbit Andi Yogyakarta.(2002)

[3]. Budiyant, Studi Pemanfaatan Motor Induksi Sebagai Generator Induksi, FT UI.(2003).

[4]. Teguh Tri Lusijarto dan Anjar Susatyo, Mengubah Motor Induksi 3 Phasa Rotor sangkar menjadi generator Induksi, kedeputian Ilmu Pengetahuan Teknik, LIPI.(2003).

[5]. Ahyanuardi. Analisis Generator Induksi Penguatan Sendiri Dengan kompensasi tegangan Menggunakan Kapasitor,FT ITB.(1999)

[6]. M. Isnaeni B.S.Motor Induksi Sebagai Generator (MISG), FT UGM.(2005)

[7]. B.Adhikary., B.Ghimire ., P. Karki, Interconnection of Two Micro Hydro Units Forming a Mini-grid System Using Soft Connection , IEEE. TENCON.(2009)

[8]. Chairul Gagarin Irianto.Suatu Studi Penggunaan Motor Induksi sebagai Generator: Penentuan Nilai Kapasitor Untuk Penyedia Daya Reaktip, JETri, Volume 3, Nomor 2.(2004). 
[9]. L.Robinson., D.G Holmes., A Single Phase Self-Exited Induction Generator With Voltage And Frequency Regulation For Use In A Remote Area Power Supply.

[10]. Manoj Kumar Arya, Steady State Analysis of Self Excited Inductiongenerator For Balanced And Unbalanced Conditions, Electrical \& Instrumentation Engineering Department, Thapar University. Patiala.(2009).

[11]. Mustafa A., A1-Saffar., Eui-Cheol Nho., Thomas A. Lipo., (1998), Controlled Shunt Capacitor Self-Excited Induction Generator, IEEE.

[12]. R. C. Bansal, Three-Phase Self-Excited Induction Generators: An Overview, IEEE, Transactions On Energy Conversion, vol. 20, no. 2.(2005).

[13]. S. N. Mahato., M. P. Sharma., S. P. Singh, Steady-State and Dynamic Behavior of a Single-Phase Self-Excited Induction Generator Using a ThreePhase Machine, International Journal of Emerging Electric Power Systems, Volume 8, Issue 3, Article 5.(2007).

[15]. Shakuntla BOORA, On-Set Theory of Self-Excitation in Induction Generator, International Journal of Recent Trends in Engineering, Vol 2, No. 5.(2009)

[16]. Wasimudin Surya S., Analisis Motor Induksi Sebagai Generator (Misg) Pada Pembangkit Listrik Tenaga Mikohidro (Pltmh), Pendidikan Teknik Elektro, Upi, Bandung.

[17]. Zuhaidi., Geri Baldi A.B, Penggunaan Metoda Newthon-Raphson Dalam Simulasi Penentuan Efek Perubahan Kecepatan Generator Induksi Tiga Fasa, Ketenagalistrikan dan Energy Terbarukan, Vol,7 No.2, Puslitbangtek.(2008)

\section{Biodata penulis}

Rahmi Berlianti,SST,MT. Lahir di Lubuk Sikaping 22 juli 1985. Menamatkan S2 Teknik
Elektro di Institut Sains dan Teknologi Nasional (ISTN) Jakarta pada tahun 2010 dan sekarang mengajar di Program Studi Teknik Listrik Politeknik Negeri Padang. 